other United Kingdom study, suggesting that HPV may have on:y a limited role in causing adenocarcinoma of the uterine cervix.

1 Wilczynski SP, Walker J, Liao S, Bergen S, Berman M Adenocarcinoma of the cervix associated with human papillomavirus. Cancer 1988;62:1331-6.

2 Smotkin D, Berek JS, Fu YS, Hacker WF, Major FI, Wettstein FO. Human papillomavirus deoxynibonucleic Weid in the uterine cervix. Obstet Gynecol 1986;68:241-4.
3 Wells M, Brown LJR. Glandular lesions of the uterine cervix: the present state of our knowledge. Histopathol 1986;10:777-92.

4 Tase T, Okagaki T, Clark BA, et al. Human papillomavirus types and localisation in adenocarcinoma and adenosquamous carcinoma of the uterine cervix: A study by in situ DNA hybridisation. Cancer Res 1988;48:993-8.

5 Tase T, Okagaki T, Clark BA, Twiggs LB, Ostrow RS, Faras AJ. Human papillomavirus DNA in adenocarcinoma in situ microinvasive adenocarcinoma of the uterine cervix and coexisting cervical squamous intraepithelial neoplasia. Int J Gynecol Pathol 1989;8:8-17.

6 Farnsworth A, Laverly C, Stoler MH. Human papillomavirus messenger RNA expression in adenocarcinoma in situ of the uterine cervix. Int J Gynecol Pathol 1989;4: 321-30.

\title{
Persistent polyclonal B lymphocytosis with Epstein-Barr virus antibodies and subsequent malignant pulmonary blastoma
}

\author{
E Lawlor, M Murray, D S O'Briain, C Blaney, L Foroni, P Sarsfield, D Condell, \\ F Sullivan, S R McCann
}

Department of Haematology, St James's Hospital, Dublin 8, Ireland E Lawlor

M Murray

F Sullivan

C Blaney

P Sarsfield

S R McCann

Department of Histopathology, St James's Hospital D S O'Briain D Condell

Laboratory of

Molecular Genetics, Department of Haematology,

Hammersmith

Hospital, London

L Foroni

Accepted for publication 23 October 1990

\begin{abstract}
Persistent polyclonal B lymphocytosis (PPBL), a rare benign lymphoproliferative disorder, occurred in a 25 year old woman. The lymphocytes showed the phenotype cIgM +, FMC7 +, CD19+, CD20 +, which was similar to that seen in Waldenstrom's macroglobinaemia, but the proliferation was repeatedly shown to be polyclonal both immunologically and by immunoglobulin gene rearrangement studies. Eleven years after presentation the patient developed a malignant pulmonary blastoma, a rare pulmonary tumour of combined epithelial and mesenchymal origin.

The failure to develop a lymphoid malignancy over 11 years together with immunological and genetic evidence of polyclonality confirms that PPBL is a benign lymphoproliferative disorder. The subsequent occurrence of a nonhaemopoietic malignancy suggests that benign lymphoid proliferations, like their malignant counterparts, may predispose to the development of neoplasia. A role for Epstein-Barr virus in the pathogenesis of one or both of these rare conditions is suggested by the finding of raised Epstein-Barr viral capsid antigen titres.
\end{abstract}

Persistent polyclonal B lymphocytosis (PPBL) is a rare disorder first described in 1982 in three patients in whom a polyclonal $B$ cell lymphocytosis with characteristic binucleate and atypical forms persisted in peripheral blood for months to years. ${ }^{1}$ The three patients were all female, middle aged, smokers, and homozygous for HLA DR 7; they had recurrent chest infections and dysgammaglobulinaemia. We report PPBL in a patient with positive Epstein-Barr virus (EBV) serology who subsequently developed a malignant pulmonary blastoma.

\section{Case report}

A 43 year old woman had had recurrent chest infections since 1976 and persistent lymphocytosis $\left(10-17.5 \times 10^{9} / 1\right)$ with binucleate and other atypical forms (fig 1A). Intermittently, splenomegaly and lymphadenopathy were present. Immunological studies in 1982 and 1986 showed a polyclonal B cell proliferation (CD19 (75\%), CD20 (40\%), FMC7 $(67 \%), \operatorname{cIgM}(65 \%), \kappa(50 \%), \lambda(30 \%))$ similar to that described in Waldenstrom's macroglobinaemia, ${ }^{2}$ but here repeatedly shown to be polyclonal. Immunoglobulin gene rearrangement studies did not detect any rearranged bands. There was a polyclonal rise in serum $\operatorname{IgM}(5.8 \mathrm{~g} / \mathrm{l})$ with low normal IgA and IgG concentrations. Repeated monospot tests were negative but an Epstein-Barr IgG viral capsid antigen (VCA) (October 1986) was positive (1/1280); Epstein-Barr IgM VCA was negative. Other viral studies for HIV, HTLVI, and human B lymphotropic virus were negative. The patient was a cigarette smoker and her HLA DR type was DR1 DR7.

In October 1986 she presented with a dry 
Figure $1 A$ Persistent polyclonal $B$

lymphocytosis: Peripheral blood mononuclear cells showing bilobed and atypical forms

(Transmission electron microscopy). Inset: $A$ binucleate lymphocyte in peripheral blood (Jenner Giemsa).

Figure 1B Pulmonary blastoma: occasional tubules lined by

cytokeratin positive cells (dark staining, arrow) are surrounded by sheets of non-reactive mesenchymal cells (avidin-biotin complex immunoenzyme technique with haematoxylin counterstaining).

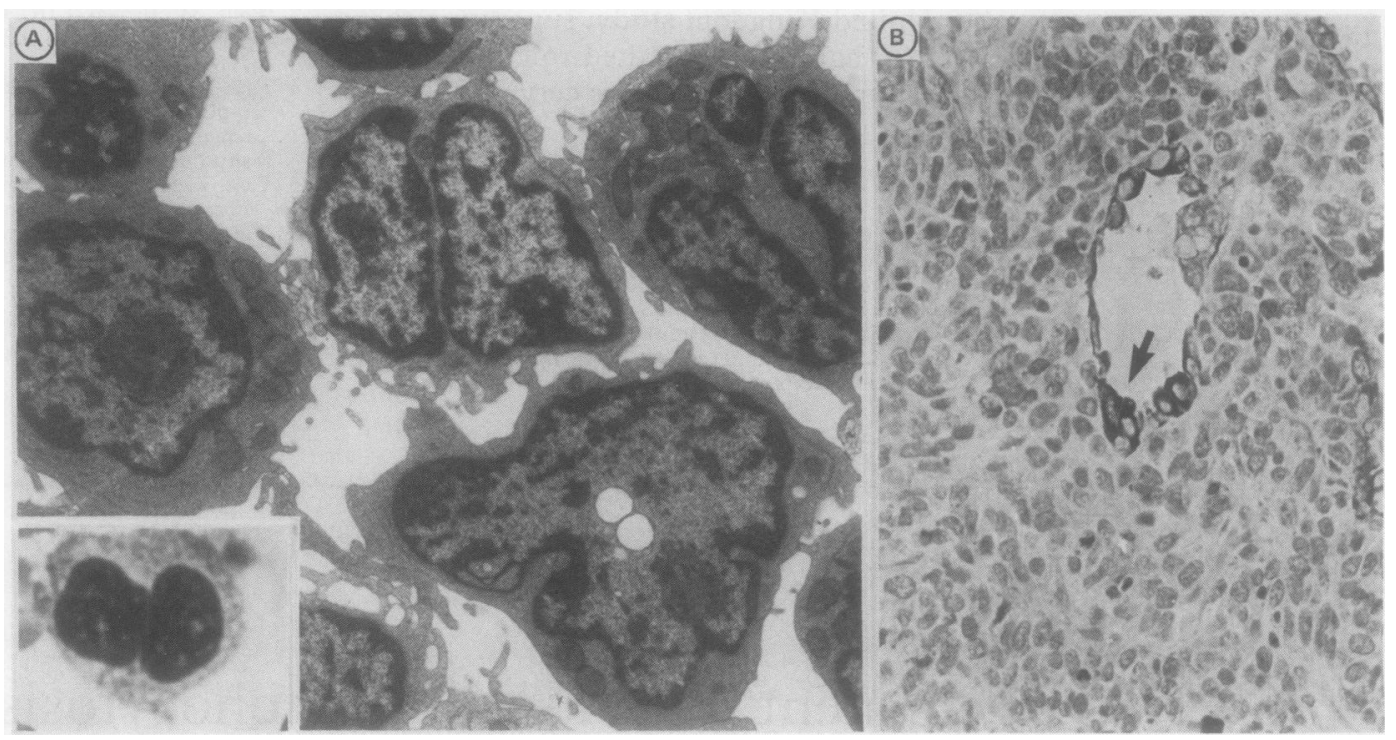

cough. A chest $X$ ray picture showed a $2 \mathrm{~cm}$ coin lesion in the left upper lobe which was resected. Histological analysis showed a malignant pulmonary blastoma (fig 1B). The patient died of idiopathic, rapidly progressive, shock lung five days postoperatively. A post mortem examination showed no evidence of lymphoma or residual blastoma.

\section{Conclusion}

Chance coexistence of these two rare disorders is unlikely and some association must be considered. The aetiology of PPBL is unknown. The 10 year course, polyclonal immunology, and absence of $B$ cell gene rearrangements indicate that it is a rare example of a true benign lymphoproliferation. The previous report of $\mathrm{PPBL}^{1}$ suggested that a viral origin was likely but the study could not show viral inclusions or convincing viral titres. Our patient had a raised Epstein-Barr VCA IgG concentration with negative IgM titres, a pattern suggestive of chronic Epstein-Barr virus infection. ${ }^{3}$

Pulmonary blastomas are rare malignant tumours which consist of both primitive mesenchymal tissue and disordered epithelial tubules resembling fetal lung tissue. ${ }^{4}$ They occur at any age (most frequently in middle age) and have a variable malignant potential. No associated haematological disorders or positive Epstein-Barr serology have been described. The development of pulmonary blastoma in this case may represent tumour evolving in the context of an underlying immune defect, smoking, and recurrent pulmonary infections. It is possible, however, that Epstein-Barr virus has a role in the aetiology of pulmonary blastoma. EpsteinBarr virus replicates primarily in epithelial tissues (with B lymphocytes only secondarily affected $)^{5}$ and has been implicated in a variety of carcinomas, notably nasopharyngeal carcinoma. ${ }^{6}$ In view of our findings of raised titres, the possible aetiological role of EpsteinBarr virus in both this pulmonary tumour and PPBL should be considered.

1 Gordon SD, Jones BM, Browning BS, Spira TJ, Laurence DN. Persistent polyclonal lymphocytosis of $\mathbf{B}$ lymphocytes. N Engl J Med 1982;307:232-6.

2 Kucharska-Pulczyska M, Ellegaard J, Hokland P. Analysi of leucocyte differentation antigens in blood and bone marrow from patients with Waldenstrom's macroglobulinaemia. Br J Haematol 1987;65:395-9.

3 Symposium proceedings. Chronic Epstein-Barr virus disease; A workshop held by the National Institute of Allergy and Infectious Disease. Ann Int Med 1985;103:951-3.

4 Fung CH, Lo J, Yonan TN, Milloy FJ, Hakami MM, Changus GW. Pulmonary blastoma; an ultrastructural study with brief review of literature and a discussion of pathogenesis. Cancer 1977;39:153-63.

5 Allday MJ, Crawford DH. The role of epithelium in EBV persistence and pathogenesis of B cell tumours. Lancet persistence and

6 Spring SB, Schluederberg A, Allen WP, Gruber J. Pathogenic diversity of Epstein-Barr virus. JNCI 1989;87. genic 